\title{
Diversity and Structure of the Prokaryotic Communities Indigenous to Two Volcanic Lakes: Nyos and Monoun in Cameroon
}

\author{
Paul-Alain Nana ${ }^{1}$, Moïse Nola ${ }^{2}$, Geneviève Bricheux ${ }^{3}$, Zéphyrin Fokam ${ }^{4}$, Pierre Ngassam ${ }^{2}$, \\ Dickson Achuo Enah ${ }^{2}$, Jonathan Colombet ${ }^{3}$, Agnès Vellet ${ }^{3}$, Anne Mone ${ }^{3}$, Viviane Ravet ${ }^{3}$, \\ Didier Debroas ${ }^{3}$, Télesphore Sime-Ngando ${ }^{3}$
}

\author{
${ }^{1}$ Department of Oceanography, Institute of Fisheries and Aquatic Sciences, University of Douala, Douala, Cameroon \\ ${ }^{2}$ Laboratory of Hydrobiology and Environment, Faculty of Science, University of Yaoundé I, Yaoundé, Cameroon \\ ${ }^{3}$ Laboratory Microorganisms: Genome and Environment, UMR CNRS 6023, Clermont Auvergne University, Clermont-Ferrand, \\ France \\ ${ }^{4}$ Department of Biology, Higher Teacher Training College, University of Bamenda, Bamenda, Cameroon \\ Email: *nanapaul4life@yahoo.fr
}

How to cite this paper: Nana, P.-A., Nola, M., Bricheux, G., Fokam, Z., Ngassam, P., Enah, D.A., Colombet, J., Vellet, A., Mone, A., Ravet, V., Debroas, D. and Sime-Ngando, T. (2020) Diversity and Structure of the Prokaryotic Communities Indigenous to Two Volcanic Lakes: Nyos and Monoun in Cameroon. Open Journal of Ecology, 10, 632-650.

https://doi.org/10.4236/oje.2020.109039

Received: July 16, 2020

Accepted: September 22, 2020

Published: September 25, 2020

Copyright ( 2020 by author(s) and Scientific Research Publishing Inc. This work is licensed under the Creative Commons Attribution International License (CC BY 4.0).

http://creativecommons.org/licenses/by/4.0/ (c) (i) Open Access

\begin{abstract}
This study explores the diversity and structure of prokaryotic communities (Archaea and Bacteria) of 2 tropical volcanic lakes (Nyos and Monoun) in Cameroon, using 16SrRNA sequences. Metagenomics analysis of sequences showed that most OTUs (Operational Taxonomic Units) were associated with 26 phyla (23 for Bacteria and 3 for Archaea) in Nyos and 36 phyla (33 for Bacteria and 3 for Archaea) in Monoun. In both lakes, Proteobacteria for Bacteria and Crenarchaea for Archaea were predominant and present at all depths but in different proportions. Bacterial community compositions were generally dominated by members of Proteobacteria, Firmicutes, Actinobacteria, Chloroflexi and Bacteroidetes covering about $98 \%$ of the sequences. Crenarchaea, Thaumarchaea and Euryarchaea were the three main phyla of Archaea common to both lakes. The amount of virus and total bacteria was determined by flow cytometry technic and the evaluated ratio ranged from 0.2 to 1.2 at Nyos and from 0.6 to 2.6 at Monoun. For both lakes, the correlation was very significant between viruses and total bacteria. The depth-dependent variability is discussed with chemical and physical environmental parameters. These could significantly influence virus-mediated bacterial lysis and abundance and vertical stratification of the prokaryotic community.
\end{abstract}

\section{Keywords}

Bacteria, Flow Cytometry, Lakes Nyos and Monoun, OTUs, Viruses 


\section{Introduction}

Crater lakes are strongly influenced by volcanic or post-volcanic activities due to their position, act as chemical traps for magmatic volatiles. The Eruption can happen if high gas fluxes from magma find favourable conditions for gas accumulation into lake waters, gaseous. Lakes Nyos and Monoun (Cameroon) and Kivu (Republic Democratic of Congo) are the only three crater lakes in the Africa known to be rich in dissolved $\mathrm{CO}_{2}$ [1]. Catastrophic $\mathrm{CO}_{2}$ outgassing occurred on $15^{\text {th }}$ August 1984 at Lake Monoun and on $21^{\text {st }}$ August 1986 at Lake Nyos, killing 37 and 1746 people, respectively [2] [3] [4] [5]. From these two dramatic events the attention on these killer lakes has increased.

Until now, scientific researches on these two lakes have mainly focused on the age of the gases at the origin of the disaster, the reverse of the $\mathrm{CO}_{2}$ supersaturated hypolimnion [6] [7], the composition and concentrations of the physico-chemical elements [1], the escape chronology of gases, the presence of isotopes and rare gases [8], and the degassing process [9]. In the two lakes, data on biological communities, mainly those on microbial assemblages are scarce, with no interest regarding the communities of viruses. Bacterial and archaeal communities of these two lakes were only recently considered by Tiodjio et al. [10] [11]. Using a molecular method, these authors highlighted the vertical distribution of bacterial communities and Archaea in Lakes Nyos and Monoun. They concluded that Lake Nyos is mostly colonized by Proteobacteria for Bacteria and by Thaumarcheota for Archaea [10], while in Monoun, the retrieved sequences were affiliated to 6 bacterial phyla dominated by Proteobacteria and to 2 archaeal phyla: Euryarchaeota and Thaumarchaeota [11]. Nyos and Monoun are meromictic lakes where the water masses are permanently stratified into layers that do not interact with each other [12].

Prokaryotic communities are well known as critical players in the cycling of energy and matter in aquatic systems, and in the related biogeochemical processes [13] [14] [15]. However, there is still a controversy about the mechanisms regulating bacterial production. Two major mechanisms controlling bacterial production have been proposed, the top-down grazing by protozoans [16], and the bottom-up availability of resources [16] [17]. Recent findings indicate that viral lysis is a further key top-down factor in the microbial food web [18] [19] [20]. Viruses are now considered to constitute an important component of aquatic microbial communities. They have been shown to be the most abundant biological entities in the plankton, where they play a crucial role in bacterial mortality and diversity [21] [22] [23]. Typically, viral infections are responsible for $20 \%-50 \%$ of daily prokaryotic mortality, and they are a major source of dissolved organic matter [24] [25] [26].

In this study, we sampled the water column of Lake Nyos and Monoun and analysed viral communities with their potential prokaryotic hosts. We had four objectives: 1) analyze the diversity of prokaryotes (Bacteria and Archaea) by high throughput sequencing; 2) evaluate and compare the total abundances of pro- 
karyotes and viruses using flow cytometry 3) study the vertical distribution of both communities; and 4) correlate these microbiological data with physico-chemical parameters in order to understand the putative influence of abiotic variables on the abundance and community structure of prokaryotes and viruses.

\section{Study Methods}

\subsection{Study Area}

Lakes Nyos and Monoun are volcanic crater lakes, located respectively in the Wum sub-division at the Northwest region and in the Noun sub-division at the West region of Cameroon. Both regions are located within the Oku volcanic field, along the Cameroon Volcanic Line (CVL) which runs from the Atlantic Ocean to the interior of Cameroon (Figure 1) [27]. The volcanism of the CVL is mostly basaltic and is about 4000 years old [28]. Lake Nyos $\left(06^{\circ} 26^{\prime} 23.0^{\prime \prime} \mathrm{N}\right.$ and $\left.10^{\circ} 18^{\prime} 02.3^{\prime \prime} \mathrm{E}\right)$ is a circular maar, approximately $230 \mathrm{~m}$ deep with a surface area of $1.58 \mathrm{~km}^{2}$ [29] (Figure 2). Its water column can be divided into four layers separated from each other by an upper and a lower chemocline, including three mixolimnic layers, i.e. epilimnion (between 0 and $-55 \mathrm{~m}$ ); metalimnion (from -55 to $-180 \mathrm{~m}$ ), and hypolimnion (extends from -180 to $-200 \mathrm{~m}$ ), and the deep monimolimnion (from $-200 \mathrm{~m}$ to the bottom of the lake). Just like Lake Nyos, Lake Monoun (Figure 2) $\left(05^{\circ} 35^{\prime} \mathrm{N}\right.$ and $10^{\circ} 35^{\prime} \mathrm{E}$, the surface area of $\left.0.31 \mathrm{~km}^{2}\right)$ is also a meromictic lake with similar layers: epilimnion ( 0 to $-25 \mathrm{~m}$ ), metalimnion ( -25 to $-55 \mathrm{~m}$ ), hypolimnion ( -55 to $-100 \mathrm{~m}$ ), and the deep monimolimnion (from $-100 \mathrm{~m}$ to the bottom of the lake) [1] [9] [30].

\subsection{Sampling}

The water samples were collected during the dry season in April 2015 in Lake Nyos and November 2016 in Lake Monoun. Water samples were collected using a horizontally-positioned $10 \mathrm{~L}$ Van Dorn bottle at 13 different depths in Lake Nyos and 10 depths in Lake Monoun. For each lake-water sample, $1 \mathrm{~L}$ was transferred to polyethylene bottle to measure chemical parameters. Simultaneously, $10 \mathrm{~mL}$ of sample were fixed with $0.2 \mathrm{~mL}$ of paraformaldehyde (PFA buffer $1 \%)$ for analysis of microbial abundances. The samples were kept at $4^{\circ} \mathrm{C}$. Prokaryotic DNA was collected from $200 \mathrm{~mL}$ filtered on $0.2-\mu \mathrm{m}$-pore-size polycarbonate filters (Sartorius) for Bacteria and on $0.45 \mu \mathrm{m}$ pore-size cellulose acetate (Whatman) for Archaea and stored at $4^{\circ} \mathrm{C}$ until nucleic acid extraction.

\subsection{Physicochemical Parameters}

Water Hydrogen potential $(\mathrm{pH})$ was determined using a $\mathrm{pH}-$ meter (SCHOTT-CG 818). Ammonium $\left(\mathrm{NH}_{4}^{+}\right)$, Nitrite $\left(\mathrm{NO}_{2}^{-}\right)$, Sulfate $\left(\mathrm{SO}_{4}^{2-}\right)$, Salinity, Suspended Solids, Total Dissolved Solids (TDS), Electrical Conductivity (EC), Turbidity, Resistivity, Color and Redox Potential were analyzed spectrophotometrically using a HACH DR $/ 2800^{\circledR}$ multifunction machine, according to APHA [31]. 


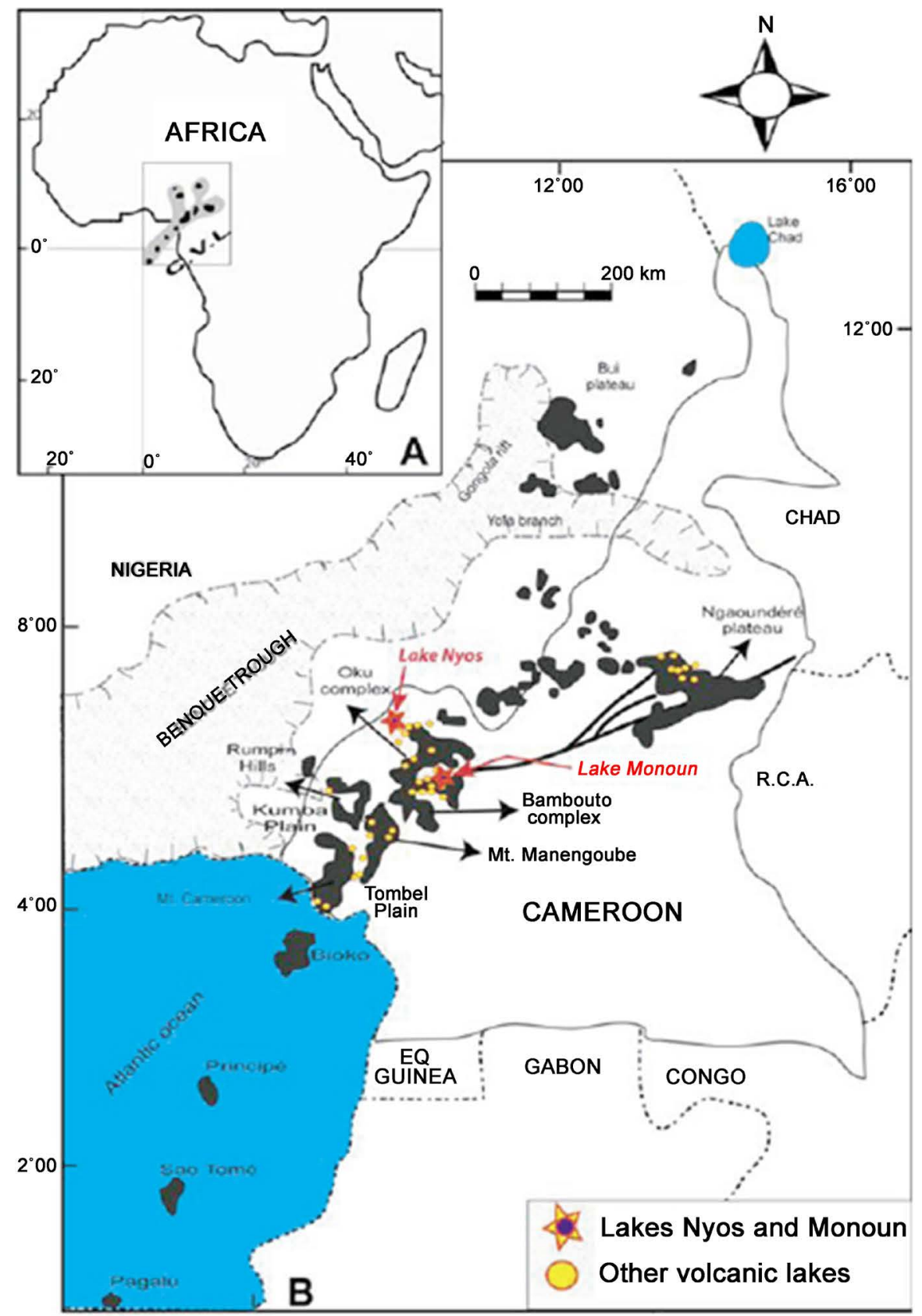

Figure 1. Location of lakes Nyos and Monoun along the CVL together with other volcanic lakes in Cameroon [27].
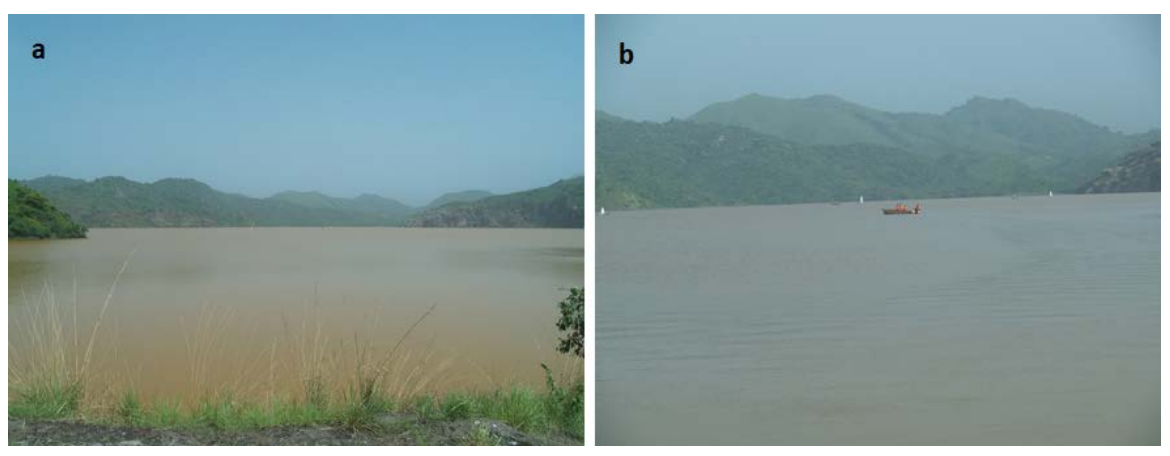

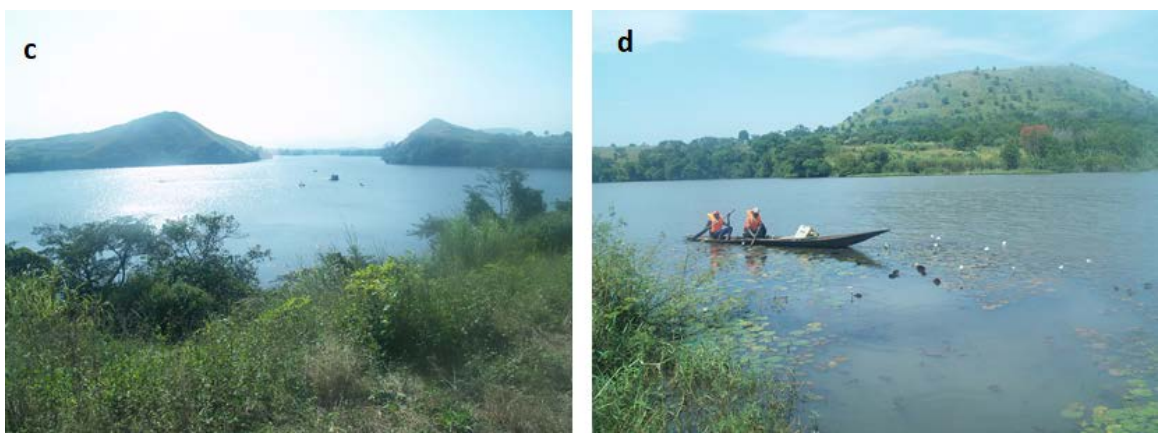

Figure 2. View of part of Lake Nyos (a) and (b) and Lake Monoun (c) and (d).

\subsection{Abundances of Viruses and Prokaryotes}

Abundances of prokaryotes and viruses were determined using a FACS Calibur flow cytometer (Becton Dickinson) equipped with an air-cooled laser providing $15 \mathrm{~mW}$ at $488 \mathrm{~nm}$ with the standard filter set-up as described by Marie et al. [32] [33] [34]. Briefly, samples were diluted with $0.2 \mu \mathrm{M}$ prefiltered TE buffer (10 $\mathrm{mM}$ Tris-HCL and $1 \mathrm{mM}$ EDTA, $\mathrm{pH} 8)$ and stained with SYBR ${ }^{\circledR}$ Green I $(10,000$ fold dilution of commercial stock, Molecular Probes, Eugene, OR, USA). The mixture was incubated for $5 \mathrm{~min}$, heated for $10 \mathrm{~min}$ at $80^{\circ} \mathrm{C}$ in the dark and cooled for 5 min prior to analysis. Prokaryotes and viruses differing in fluorescence intensity were detected by their signature in a side scatter SSC versus green fluorescence plot (530 nm wave-length, fluorescence channel 1 of the instrument). Flow cytometry data acquisitions were analyzed using CellQuest Pro software (BD Biosciences, version 4.0).

\subsection{DNA Extraction, PCR Amplification of $16 \mathrm{~S}$ rRNA Gene and Sequencing}

DNA extraction was performed with our previously modified protocol [35]. Filters were covered with TE $1 \times$ buffer, $60 \mathrm{mg}$ of $0.1 \mathrm{mM}$ Glass beads were added and samples were homogenized in a bead beater ( 3 pulses for $30 \mathrm{~s}$ at $30 \mathrm{~Hz}$ ). Tubes were centrifuged $1 \mathrm{~min}$ at $600 \times \mathrm{g}$ and supernatant was retained. EDTA $(0.5 \mathrm{M} \mathrm{pH}$ 8) and a lysozyme solution (final concentration $250 \mu \mathrm{g} / \mathrm{mL}$ ) were added and samples were incubated at $37^{\circ} \mathrm{C}$ for $30 \mathrm{~min}$. Then sodium dodecyl sulfate $(10 \%)$ and proteinase $\mathrm{K}$ (final concentration $100 \mu \mathrm{g} / \mathrm{mL}$ ) were added, and samples were incubated at $37^{\circ} \mathrm{C}$ for at least $60 \mathrm{~min}$. A cetyltrimethyl ammonium bromide (CTAB) solution (final concentration, $1 \%$ in a $0.7 \mathrm{M} \mathrm{NaCl}$ solution) was added, and samples were incubated at $65^{\circ} \mathrm{C}$ for $10 \mathrm{~min}$. Nucleic acids were extracted with chloroform-isoamyl alcohol (24:1); the aqueous phase containing nucleic acids was kept and purified by adding phenol-chloroform-isoamyl alcohol (25:24:1). After isopropanol (0.6 volume) addition, the nucleic acids were precipitated at $-20^{\circ} \mathrm{C}$ for $12 \mathrm{~h}$. After centrifugation, the DNA pellet was ethanol rinsed and suspended in $50 \mu \mathrm{L}$ of water. The DNA yield was quantified by a fluorescence assay (Quant-iT Pico Green dsDNA Assay Kit), and nucleic acid extracts were stored at $-20^{\circ} \mathrm{C}$ until analysis. 
Amplification of the V3/V4 region of the 16S rRNA was performed using the universal primer 515F (5'-GTGYCAGCMGCCGCGGTA-3') and bacteria/archaea specific primer 909R (5'-CCCCGYCAATTCMTTTRAGT-3') [36]. 18S rRNA gene was amplified with the foward universal primer $515 \mathrm{~F}$ and the specific reverse primer 951R (TTGGYRAATGCTTTCGC). Primers were modified by adding barcodes in both cases. Each PCR was performed in a total volume of $30 \mu \mathrm{L}$ containing $3 \mu \mathrm{L}$ of $10 \times \mathrm{NH}_{4}$ reaction buffer, $1.2 \mu \mathrm{L}$ of $50 \mathrm{~mm} \mathrm{MgCl}_{2}, 0.15 \mu \mathrm{L}$ of Eurobio TaqII (Eurobio, $5 \mathrm{U} / \mu \mathrm{L}$ ), $0.6 \mu \mathrm{L}$ of $10 \mathrm{mM}$ of each dNTP, $0.3 \mu \mathrm{L}$ of $50 \mathrm{mg} / \mathrm{mL}$ BSA and 1.2 $\mu \mathrm{L}$ of each $5 \mu \mathrm{M}$ primer. The amplification conditions consisted of initial denaturation at $94^{\circ} \mathrm{C}$ for $5 \mathrm{~min}$ followed by 30 cycles for $1 \mathrm{~min}$ at $94^{\circ} \mathrm{C}, 45 \mathrm{~s}$ at $58^{\circ} \mathrm{C}$ (Bacteria and Archaea), $45 \mathrm{~s}$ at $55^{\circ} \mathrm{C}$ (Eucaryotes) and $45 \mathrm{~s}$ at $72^{\circ} \mathrm{C}$, and a final elongation of $7 \mathrm{~min}$ at $72^{\circ} \mathrm{C}$. The PCR products were run on a $2 \%$ agarose gel electrophoresis, the amplicons were purified and concentrated using the MiniElute gel extraction kits $\left(\right.$ Qiagen $\left.{ }^{\circledR}\right)$, and quantified using the Agilent 2200 Tape Station system and the D1000 Screen Tape kit (Agilent Technologies). Tagged amplicon pools were constructed in a concentration of $20 \mathrm{ng} / \mu \mathrm{L}$ for Illumina Sequencing Technology (Run type: Paired end-Read length: $2 \times 250 \mathrm{bp}$ ) by GATC Biotech.

\subsection{Bioinformatic and Statistical Analysis}

The MiSEQ data were assembled with the vsearch tool (https://github.com/torognes/vsearch) and the sequences were cleaned as follows: sequences were removed if they presented ambiguous bases " $N$ ", a length shorter than $200 \mathrm{bp}$, and had a mismatch in the forward and reverse primers. The putative chimaeras were detected by vsearch. The remaining rRNA $16 \mathrm{~S}$ sequences were clustered into "molecular species" (OTU) at a 97\% similarity threshold according to Kim et al. [37] with vsearch (option cluster small sorted by length) and OTUs representing less than $0.005 \%$ of the total sequences were removed. The representative sequence for each OTU was then inserted into phylogenetic trees for taxonomic annotation. The seed OTUs were affiliated by similarity and phylogeny from reference sequences. These microbial references were extracted from the SILVA database [38] according to the following criteria: length $>1200 \mathrm{bp}$, quality score $>75 \%$ and a pintail value $>50$. After comparing the OTUs with the reference sequences using a similarity approach (vsearch tool), trees including OTUs with their closest references were built with FastTree [39]. The different taxonomic affiliations obtained were checked for inconsistency. This process was implemented using the pipeline PANAM (Phylogenetic Analysis of Next-generation AMplicons https://github.com/panammeb/) [40]. Finally, 360,794 sequences binned in 4609 OTUs were obtained for Bacteria and Archaea. Subsequent analyses were made with the package Phyloseq implemented under R [41].

\section{Result}

\subsection{Abiotic Variables}

The $\mathrm{pH}$ varied from 5.81 to 9.86 in Lake Nyos, and from 6.99 to 7.77 in Lake 
Monoun. This high value ( $\mathrm{pH}$ 9.86) at Nyos was observed between epilimnion and metalimnion. Concentrations of ammonium, nitrite, suspended solids, salinity and turbidity were very low and relatively constant in both lakes. The TDS and EC values showed similarities, with decreased values in the epilimnion, then a sudden increase in metalimnion and a gradual decrease in hypolimnion. The maximum color values were at $67 \mathrm{Pt} . \mathrm{C}$ (Platinum-Cobalt) at $130 \mathrm{~m}$ depth and 13,592 Pt.C at $122 \mathrm{~m}$ at Nyos and Monoun respectively. It should be noted that the resistivity values did not vary with depth. The values of several of these parameters were often very high in the monimolimnion $(112 \mathrm{~m})$ rich in sediments at Monoun Lake.

For each lake, a redundancy analysis was performed between physico-chemical parameters and biological parameters as a function of depth. In Lake Nyos, there was a strong positive correlation between abiotic parameters such as suspended solids, $\mathrm{NO}_{2}^{-}, \mathrm{SO}_{4}^{2-}$, water color, turbidity and the abundance of viruses and prokaryotes on the surface of epilimnion. In addition, this set of parameters was distinct from two other negatively correlated sets, namely (redox potential, $\mathrm{pH}$ and resistivity) and (salinity, EC, TDS and $\mathrm{NH}_{4}^{+}$) (Figure 3(a)). In Monoun Lake monimolimnion, turbidity, suspended solids, $\mathrm{NO}_{2}^{-}, \mathrm{SO}_{4}^{2-}$, and $\mathrm{NH}_{4}^{+}$ were positively correlated with virus and prokaryotic abundances (Figure 3(b)). TDS and salinity were negatively correlated with $\mathrm{pH}$, resistivity and redox potential.

\subsection{Prokaryotic Community Composition}

The richness and abundance of the prokaryotic community was a bit different in the two lakes studied. This prokaryotic community varied according to the depth of the waters. Bacteria and Archaea were detected in both lakes. However, some groups of Bacteria and Archaea were common to both lakes. At Lake Nyos, 26 phyla have been identified (Figure 4(a)); of which 23 for Bacteria and 3 for Archaea. At Monoun, a total of 36 phyla (33 for Bacteria and 3 for Archaea) were recorded (Figure 4(b)).

The phylum of Proteobacteria was the most representative and relatively the most abundant in both lakes. Chloroflexi and Chlorobi were predominantly identified in the hypolimnion of both lakes. At Lake Monoun, the Firmicutes and Cyanobacteria were present in epilimnion and metalimnion. The Bacteroidetes, less abundant at Nyos, were concentrated in the hypolimnion at Monoun. Bacteria belonging to the class of Gammaproteobacteria, Betaproteobacteria and Alphaproteobacteria were found extensively in all the depths of the lakes. The class of Gammaproteobacteria represented the highest proportion of Proteobacteria sequences. The class of Ignavibacteria, was found only at Lake Nyos whereas the Classes Acidobacteria, Bacilli, Clostridia, Cyanobacteria, Dehalococcoidia, Deinococci, Miscellaneous Crenarchaeotic Group, Planctomycetacia and Sphingobacteria have not been identified in Nyos (Figure 5). Crenarchaea, Thaumarchaea and Euryarchaea were the three phyla of Archaea common to both lakes. 

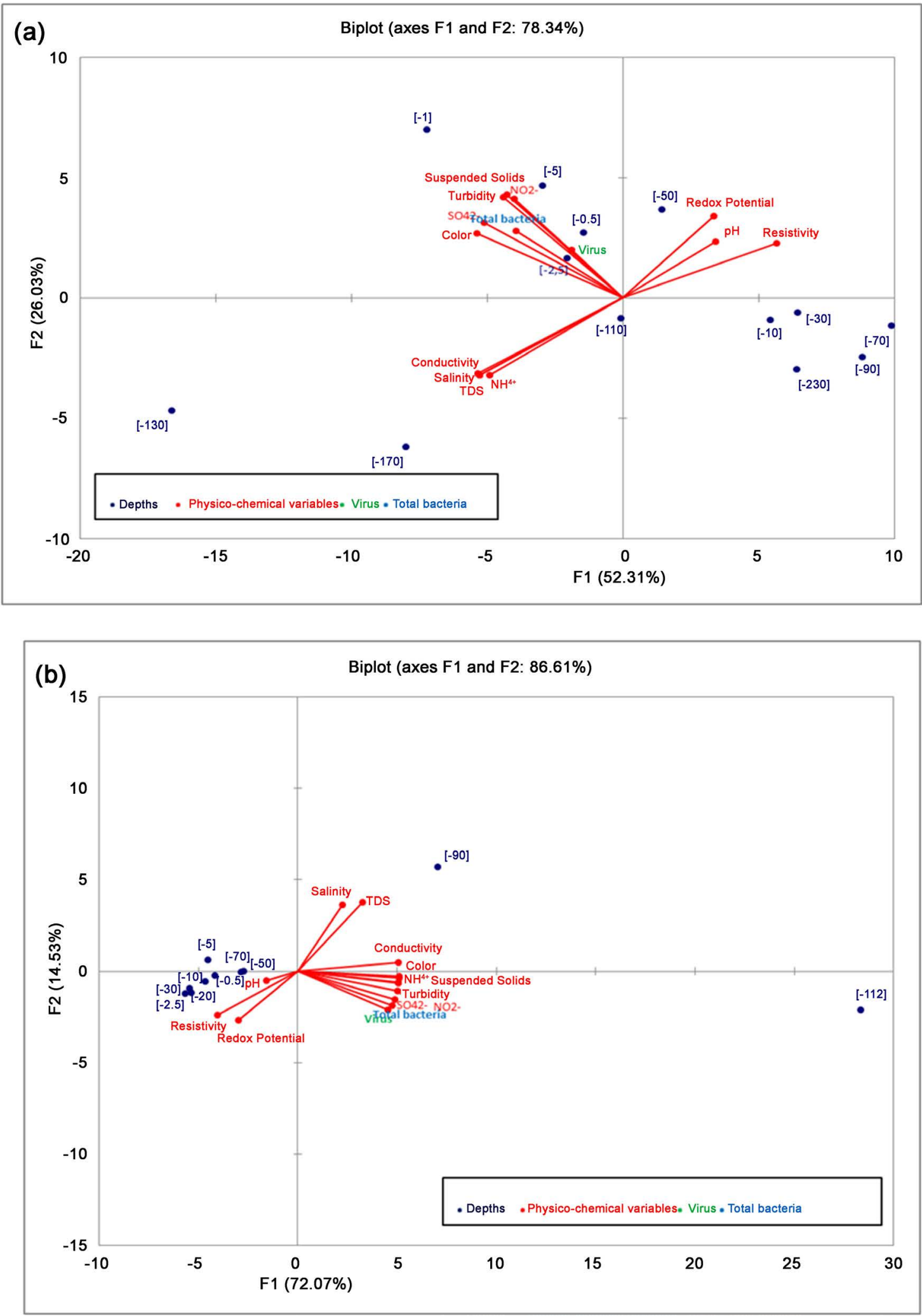

Figure 3. Redundancy analysis showing physico-chemical variables and their influence on bacterial and viral distribution and abundance. (a) Lake Nyos: the combination of environmental variables accounted for $78.34 \%$ of the total variance in bacterial abundance and viral particles; (b) Lake Monoun: the combination of environmental variables accounted for $86.61 \%$ of the total variance in bacterial abundance and viral particles. 
(a)

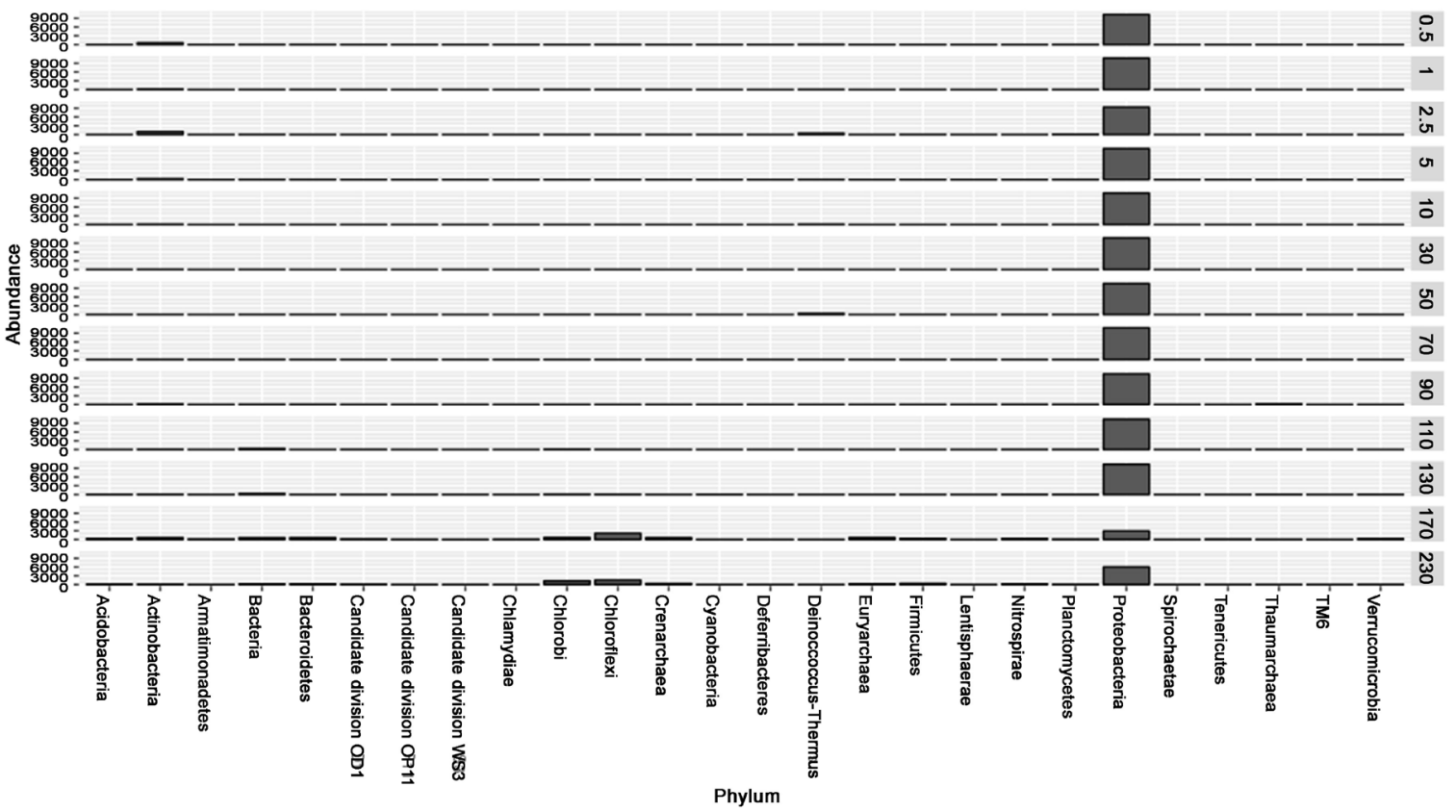

(b)

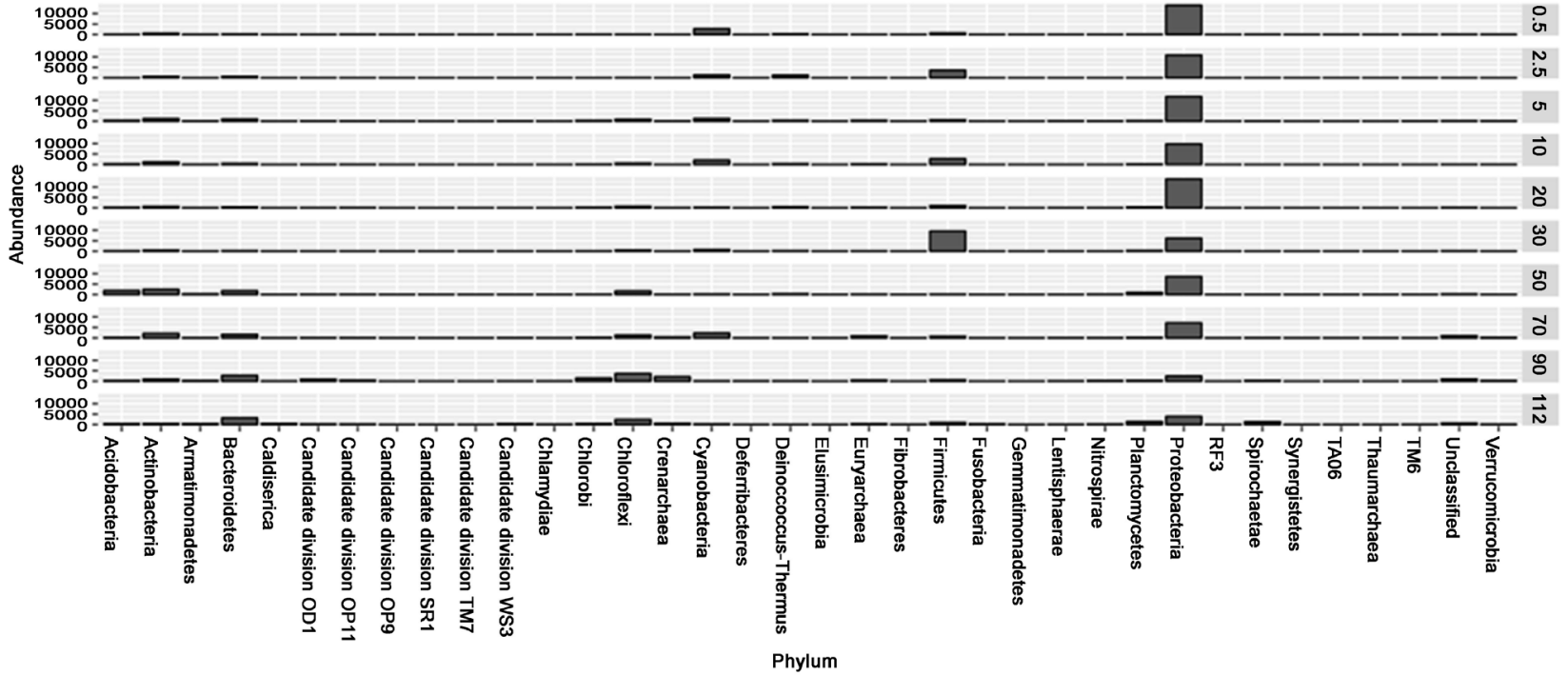

Figure 4. Richness and abundance of prokaryotes as a function of depth. (a) Lake Nyos; (b) Lake Monoun.

\subsection{Viral and Bacterial Abundance and Distribution}

In Lake Nyos, bacterial abundance was higher than viral abundance along with the vertical profile (Figure 6(a)). In the hypolimnion, we recorded $1.35 \times 10^{5}$ to $5.20 \times 10^{5}$ bacterial cells per milliliter of sample and $6.60 \times 10^{4}$ to $3.50 \times 10^{5}$ viral particles per milliliter of sample. The mean VBR (Ratio of Viruses to Bacteria) of the Lake Nyos was at 0.42 (range: 0.2 to 1.2 ). Generally, we observed that abiotic parameters such as turbidity, suspended solid, color, $\mathrm{NO}_{2}^{-}$and $\mathrm{SO}_{4}^{2-}$ had a strong positive influence on bacterial and viral abundances (Figure 4(a)).

In Monoun Lake, the dominance of viral or bacterial abundance varied with depth. Thus, from the surface of the lake down to $20 \mathrm{~m}$, then from $40 \mathrm{~m}$ to $60 \mathrm{~m}$, viruses were more abundant than total bacteria (Figure 6(b)). In the upper 

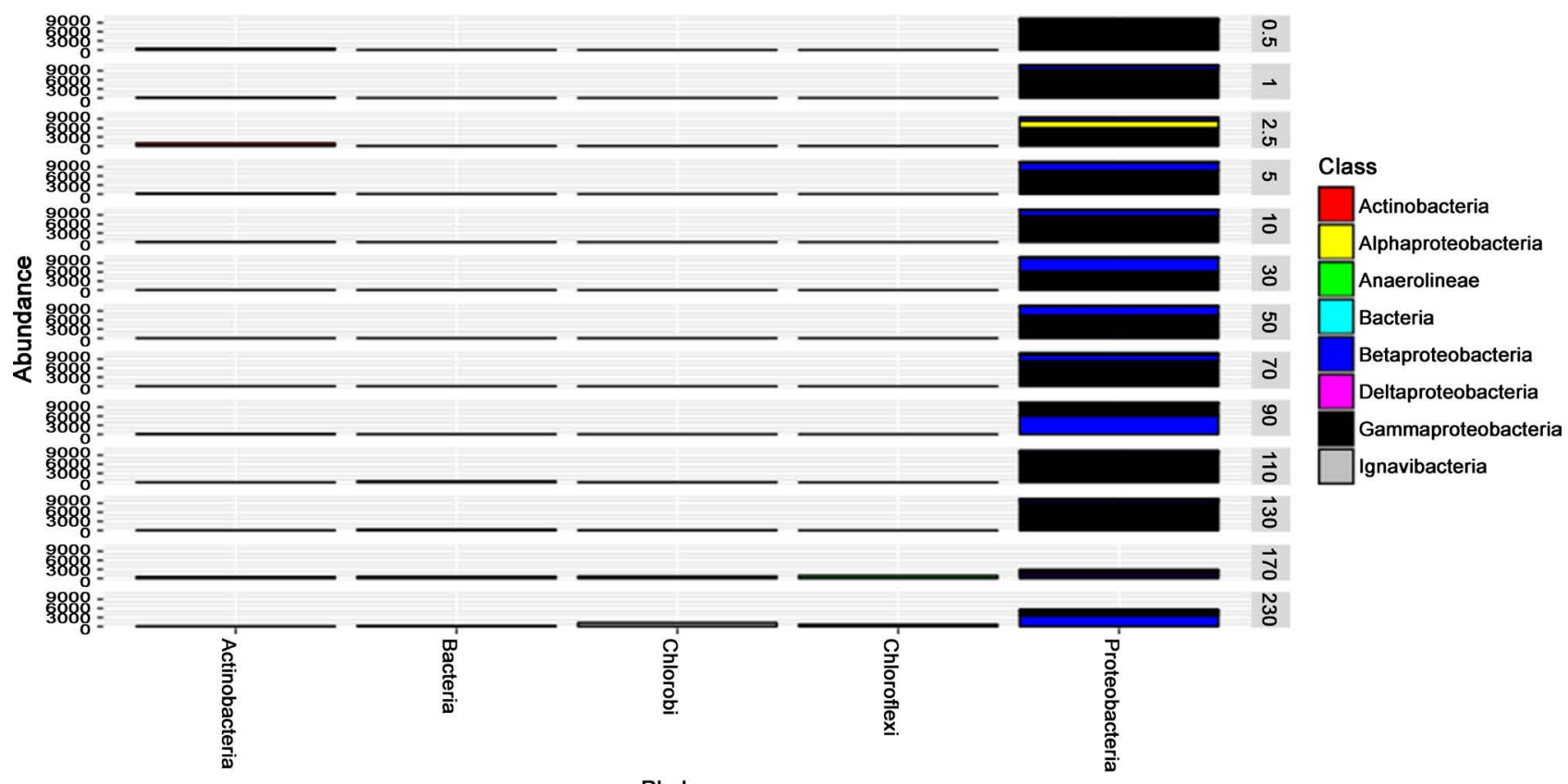

Phylum

(a)

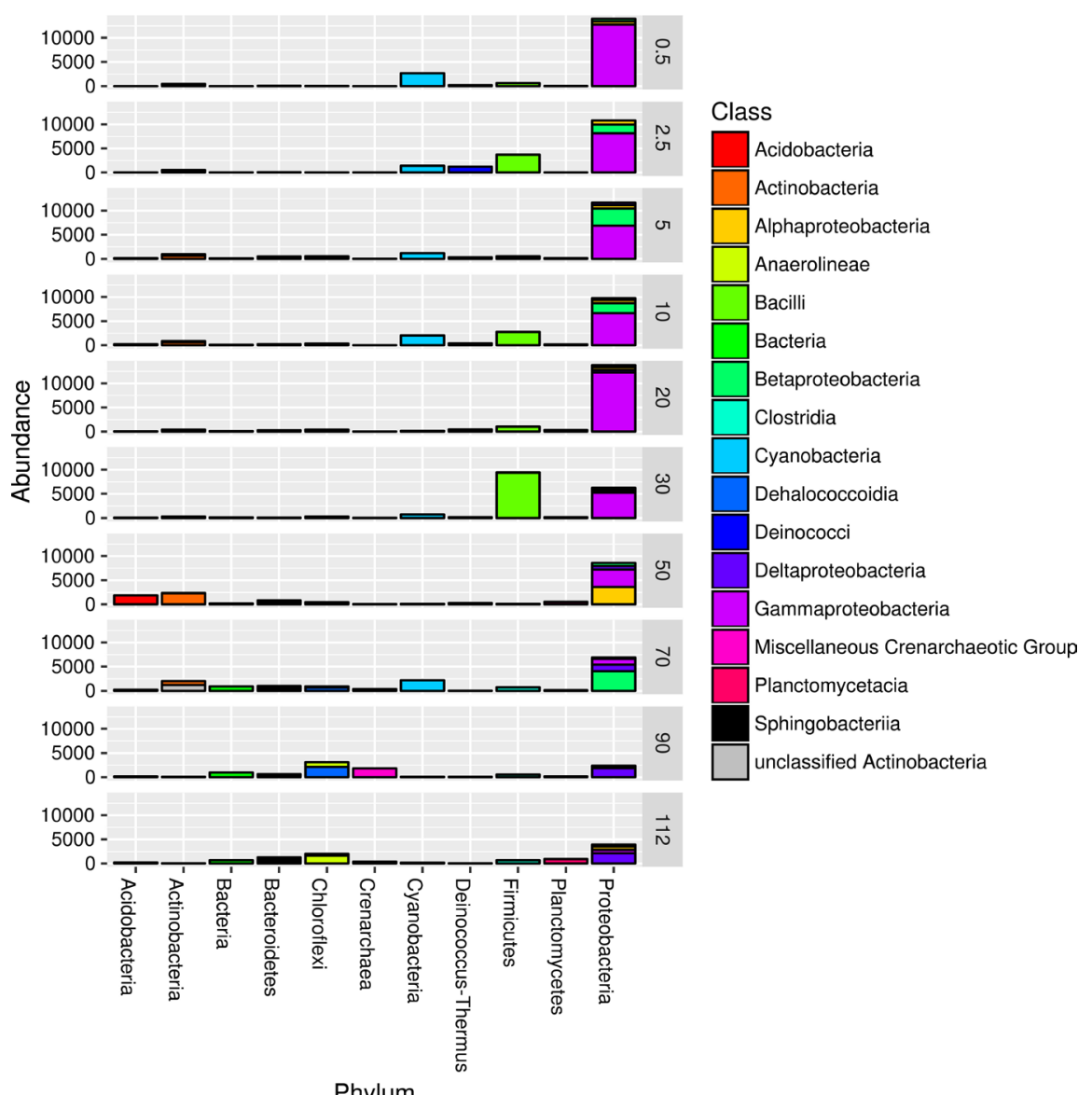

(b)

Figure 5. Dominance of proteobacteria and variations in abundance of bacterial classes as a function of depth. (a) Lake Nyos; (b) Lake Monoun. 


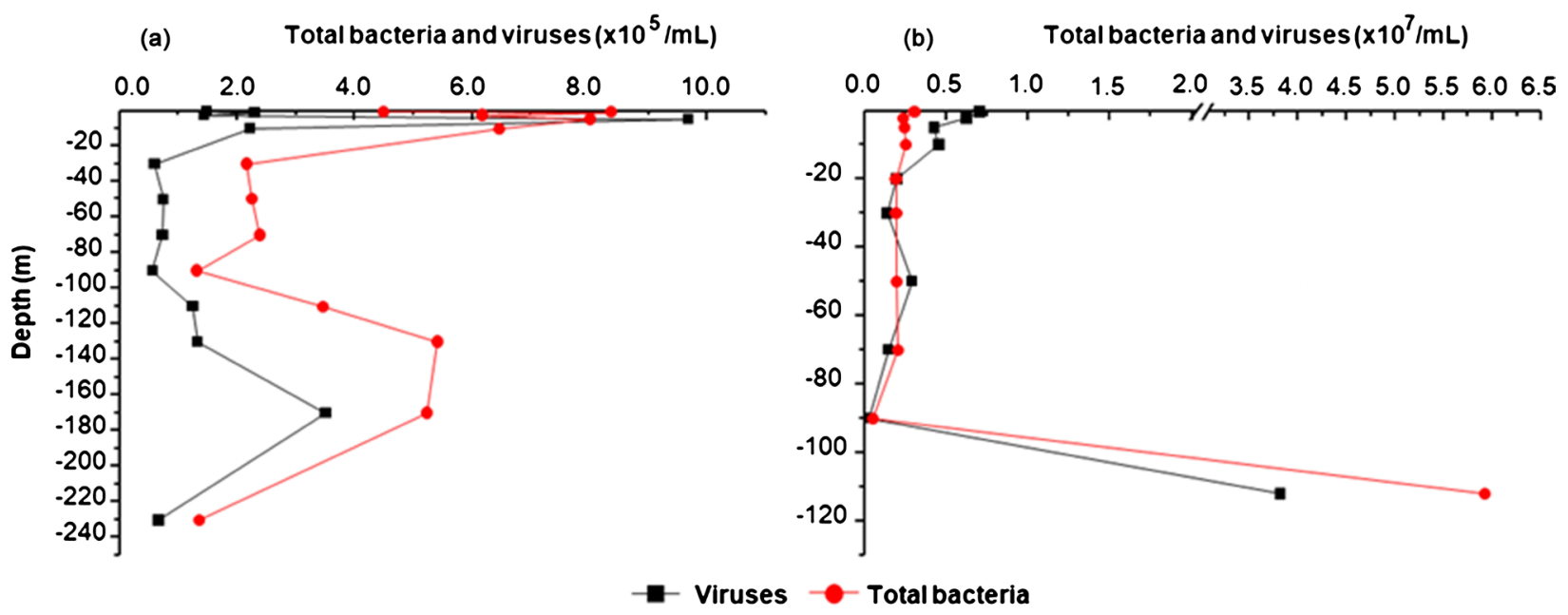

Figure 6. Variation of abundance of total bacteria and viruses as a function of depth. (a) Lake Nyos; (b) Lake Monoun.

epilimnion, we counted more virus particles than bacterial cells, with a VBR ranging between 2.30 and 2.60. In the metalimnion, bacterial and viral abundance were relatively high $\left(\sim 5.92 \times 10^{7}\right.$ bacterial cells per milliliter sample and $\sim 3.82 \times 10^{7}$ virus particles per milliliter sample). In the hypolimnion, which is very rich in sediments, the bacterial and viral abundances were the highest compared to other layers of the lake. In this deep part of Monoun Lake, the VBR varied between 0.5 and 0.6. The redundancy analysis in these lake showed that the abundance of total bacteria and viruses were positively influenced by turbidity, suspended solid, color, $\mathrm{NO}_{2}^{-}$and $\mathrm{SO}_{4}^{2-}$ (Figure 3(b)).

By studying bacterial and viral abundance in Nyos and Monoun Lakes, we have observed, according to the depths, some differences. Bacterial and viral abundance was approximately 75 -fold higher in Lake Monoun than in Lake Nyos. The VBR greater than 1 at Monoun Lake suggests intense phage activity compared to Lake Nyos. For both lakes, the correlation was very significant between viruses and total bacteria (Nyos: rho $=0.89$ p-value $<2.2 \mathrm{e}-16$ and Monoun: rho $=0.92 \mathrm{p}$-value $<1.3 \mathrm{e}-5$ )

\section{Discussion}

\subsection{Diversity and Distribution of Prokaryote}

Our study, based on small rRNA subunit analysis, revealed the diversity and vertical distribution of native prokaryotes from two tropical volcanic lakes of Cameroon (Figure 4 and Figure 5). We counted 26 phyla and 36 phyla at Nyos and Monoun respectively. From epilimnion to hypolimnion in both lakes, the majority of bacterial sequences belonged to Proteobacteria, a regularly reported observation for hypersaline and hyperalcalin lakes [42], as well as in freshwaters [43]. Gammaproteobacteria accounted for the largest proportion of Proteobacteria sequences in Nyos and Monoun [10] [11], although they are not abundant in freshwater lakes [43] [44]. Alphaproteobacteria have been particularly noted in the epilimnion of Nyos, in the epilimnion and the metalimnion of Monoun. 
These results are not very different from those obtained by Humbert et al. [45] in six tropical lakes in Burkina Faso. These authors showed a predominance of Cyanobacteria then Alphaproteobacteria in all the depths of the lakes studied. In the meantime, Deltaproteobacteria, absent from sediment-poor Lake Nyos, have been identified in the hypolimnion of Monoun Lake, which is very rich in sediment. This confirms the hypothesis that Deltaproteobacteria evolve mainly in sediment-rich benthic environments [46] [47]. Similar results were found in Lake Tanganyika [48] [49] and Lake Kivu [50], two meromictic lakes rich in sediment. In addition to the existence of the bacterial community in the two lakes studied, we noted the presence of a small community of Archaea. Based on the species richness in both lakes, a divergence between the two microbial communities was revealed. Thus, according to the quantification data obtained, the Bacteria were numerically dominant relative to the archaea in all the samples. The three groups of Archaea namely Crenarchaea, Thaumarchaea and Euryarchaea identified are characteristic of meromictic volcanic lakes [50]. The general upward trend in the number of Archean genecopias with depth is consistent with previous results from other meromictic lakes [51].

\subsection{Abundance and Virus-Prokaryote Potential Interactions}

In this study, an assessment of abundances of total bacteria and virus particles was conducted at different depths in order to understand the interactions between these two communities. From the data obtained, we can affirm the omnipresence of total bacteria and viruses at all depths of Nyos and Monoun lakes. As in other aquatic ecosystems, they would be the most abundant biological entities in these two volcanic lakes [52] [53]. Significant correlations were revealed between viruses and total bacteria in the two lakes studied. By observing the abundance variations along the two lake profiles and the VBR values, we can hypothesize that most of these viruses are bacteriophages. Indeed, bacteriophages are responsible for much of the prokaryotic mortality [22] [52] [54]. In lakes Nyos and Monoun, as in other aquatic ecosystems, viruses are considered an integral part microbial communities and a significant source of bacterial mortality [55] [56]. According to Clokie et al. [57], viruses can mediate processes such as transduction, lysogenic conversion and succession of species and contribute to the maintenance of microbial diversity in the lakes, if this is the case for our studied lakes, these mechanisms would then be more accentuated in Lake Monoun given the richness of its species. The viral activity of Nyos and Monoun lakes would influence prokaryotic diversity and community dynamics by selective suppression of specific host populations [58]. Knowing that one of the main characteristics of the lakes we studied is their high gas content, the viruses would play an important role in the carbon cycle of lakes Nyos and Monoun by facilitating the transformation of matter and energy in microbial food webs by lysis of prokaryotic cells. The analysis of virus-prokaryotic interactions remains very little studied in tropical meromictic crater lakes, especially those in Africa. 


\subsection{Relationship between Biotic and Abiotic Parameters}

Positive correlations have been observed between some abiotic parameters and the prokaryotic and viral communities. The vertical structuring of prokaryotes in Nyos and Monoun lakes is partly related to some biological interest parameters such as turbidity, suspended solids, color, $\mathrm{NO}_{2}^{-}$and $\mathrm{SO}_{4}^{2-}$. Similar results have been obtained in other tropical lakes [59] [60] [50]. In general, several other abiotic factors that we have not been able to measure could affect the structure, diversity and abundance of microbial communities in Nyos and Monoun Lakes. This would be temperature, $\mathrm{O}_{2}, \mathrm{CO}_{2}$, salinity, nutrient availability, quantity and quality of dissolved organic matter [10] [42]. In meromictic lakes such as the ones we studied, the $\mathrm{pH}$, availability of $\mathrm{O}_{2}$ or $\mathrm{CO}_{2}$, ions and nutrients would significantly affect the abundance, activity and diversity of bacterial and archaeal populations [61]. Our data are consistent with those of Llirós et al. [62] obtained on Lake Kivu, which has almost the same characteristics as Nyos and Monoun. Turbidity, suspended solids, and ion content $\left(\mathrm{NH}_{4}^{+}, \mathrm{NO}_{2}^{-}\right.$ and $\mathrm{SO}_{4}^{2-}$ ) have been clearly shown to affect the stratification, size, activity, and diversity of bacterial populations. Thus, a change in these environmental conditions changes the importance of bacterial production [61]. Such variations within prokaryotic communities have also been observed along salinity gradients [63] [64]. The limitation of bacterial growth by phosphate has been demonstrated in different marine environments [65] [66]. The regulation of bacterial populations in Nyos and Monoun lakes is significantly correlated with viral abundance. Similar results have already been found in temperate meromictic lakes [23] [67]. Viral activity and bacterial regulation in Nyos and Monoun lakes may also vary with depth of water and sediment richness [68] [69], trophic system [70], ion content [71], turbidity [72] and suspended particles [73]. The viral community present in these two lakes would have similar roles to those of other aquatic environments with the same characteristics. To our knowledge, the detection of viral particles and the study of the virus-bacteria interaction was the first study of its kind on lakes Nyos and Monoun. We examined the viral and bacterial compartment in the different depths of the lakes in order to highlight differences and similarities in virus-bacterial interactions, compared to the widely described interactions for temperate regions. Overall, despite the generally high microbial activity observed along the Lake Nyos and Monoun profiles, we hypothesize that viral control of bacterial populations in these waters may not be as relevant as the control that has been found in lakes temperate [74].

\section{Conclusion}

This study provided important information on the composition and structure of the indigenous prokaryotic community of two volcanic lakes (Nyos and Monoun) in Cameroon (Central Africa). We noted the predominance of Proteobacteria (Bacteria) and Crenarchaea (Archaea) in both lakes. Lake Monoun (shallower) had higher species richness than Lake Nyos (deeper). In the lakes 
studied, the abundance and structure of prokaryotes varied with depth and mixing regimes suggesting that the predominant environmental factors in time and space played a crucial role in this structure. For the first time, the flow cytometry technique was used to quantify prokaryotes and virus particles in Nyos and Monoun lakes; which tells us about the virus-bacteria interactions along the profile. Thus, the higher VBR in Monoun Lake would reflect intense viral activity in this lake relative to Nyos. For our future studies on these two historic lakes, we intend to focus specifically on the functional groups of the most representative prokaryotes and eukaryotes, on the one hand, and on the other hand on determining the identity of the viral community and its role in the microbial loop and gas regulation.

\section{Acknowledgements}

For this study, Paul-Alain Nana was supported by a postdoctoral fellowship from the University of Clermont-Auvergne (France). Our sincere thanks for the logistical and financial support.

\section{Conflicts of Interest}

The authors declare no conflicts of interest regarding the publication of this paper.

\section{References}

[1] Kusakabe, M. (2015) Evolution of $\mathrm{CO}_{2}$ Content in Lakes Nyos and Monoun, and Sub-Lacustrine $\mathrm{CO}_{2}$-Recharge System at Lake Nyos as Envisaged from $\mathrm{CO}_{2 / 3} \mathrm{Hera}$ tios and Noble Gas Signatures. In: Rouwet, D., Christenson, B., Tassi, F. and Vandemeulebrouck, J., Eds., Volcanic Lakes, Springer, Heidelberg, 427-450.

https://doi.org/10.1007/978-3-642-36833-2 19

[2] Kerr, R.A. (1986) Nyos, the Killer Lake, May Be Coming Back. Science, 244, 1541-1542. https://doi.org/10.1126/science.2500707

[3] Kling, G.W. (1987) Seasonal Mixing and Catastrophic Degassing in Tropical Lakes, Cameroon, West Africa. Nature, 237, 1022-1024.

https://doi.org/10.1126/science.237.4818.1022

[4] Kusakabe, M., Nojiri, Y. and Narita, M. (1990) A Simple Plastic Syringe Sampler for in Situ Fixing of the Total $\mathrm{CO}_{2}$, Dissolved in Lake Water. International Working Group Crater Lakes Newsletter 2, 11-14.

[5] Sano, Y., Kusakabe, M., Hirabayashi, J., Nojiri, Y., Shinohara, H., Njine, T. and Tanyileke G. (1990) Helium and Carbon Fluxes in Lake Nyos, Cameroon: Constrain on Next Gas Burst. Earth and Planetary Science Letters, 99, 303-314. https://doi.org/10.1016/0012-821X(90)90136-L

[6] Tazieff, H. (1989) Mechanisms of the Nyos Carbon Dioxide Disaster and of So-Called Phreatic Steam Eruptions. Journal of Volcanology and Geothermal Research, 39, 109-116. https://doi.org/10.1016/0377-0273(89)90051-6

[7] Lockwood, J.P. and Rubin, M. (1989) Origin and Age of the Lake Nyos Maar, Cameroon. Journal of Volcanology and Geothermal Research, 39, 109-116. https://doi.org/10.1016/0377-0273(89)90052-8 
[8] Barberi, F., Chelini, W., Marinelli, G. and Martini, M. (1989) Rapport de la Mission Technique Italienne au Cameroun à la Suite de la Catastrophe du Lac Nyos (21 août 1986): Aspects Volcanologiques et Géochemiques. Report, Gruppo Nazionale par la Vulcanologica, Rome, 33 p.

[9] Kling, G.W., Evans, W.C., Tanyileke, G., Kusakabe, M., Ohba, T., Yoshida, Y. and Hell, J.V. (2005) Degassing Lakes Nyos and Monoun: Defusing Certain Disaster. Proceedings of the National Academy of Sciences of the United States of America, 102, 14185-14190. https://doi.org/10.1073/pnas.0502274102

[10] Tiodjio, R.E., Sakatoku, A., Nakamura, A., Tanaka, D., Fantong, W.Y., Tchakam, K.B., Tanyileke, G., Ohba, T., Hell, V.J., Kusakabe, M., Nakamura, S. and Ueda, A. (2014) Bacterial and Archaeal Communities in Lake Nyos (Cameroon, Central Africa). Scientific Report, 4, Article No. 6151. https://doi.org/10.1038/srep06151

[11] Tiodjio, R.E., Sakatokua, A., Issac, Fantong, W.Y., Tchakam, K.B., Tanyileke, G., Hell, V.J., Ohba, T., Kusakabe, M., Tanaka, D., Nakamura, S. and Ueda, A. (2016) Vertical Distribution of Bacteria and Archaea in a $\mathrm{CO}_{2}$-Rich Meromictic Lake: A Case Study of Lake Monoun. Limnologica, 60, 6-19. https://doi.org/10.1016/j.limno.2016.05.006

[12] Hakala, A. (2004) Meromixis as a Part of Lake Evolution; Observations and a Revised Classification of True Meromictic Lakes in Finland. Boreal Environment Research, 9, 37-53.

[13] Azam, F., Fenchel, T., Field, J.G., Graf, J.S., Meyer-Rei1, L.A. and Thingstad, F. (1983) The Ecological Role of Water-Column Microbes in the Sea. Marine Ecology, 10, 257-263. https://doi.org/10.3354/meps010257

[14] Wang, P., Joo, J., Park, B.S., Kim, J.H. and Han, M.S. (2017) Relationship between Dissolved Organic Carbon and Bacterial Community in the Coastal Waters of Incheon, Korea. Oceanological and Hydrobiological Studies, 46, 50-61. https://doi.org/10.1515/ohs-2017-0006

[15] Liu, K., Ding, X., Tang, X., Wang, J., Li, W., Yan, Q. and Liu, Z. (2018) Macro and Microelements Drive Diversity and Composition of Prokaryotic and Fungal Communities in Hypersaline Sediments and Saline-Alkaline Soils. Frontiers in Microbiology, 9, 352. https://doi.org/10.3389/fmicb.2018.00352

[16] Bettarel, Y., Sime-Ngando, T., Amblard, C. and Dolan, J. (2004) Viral Activity in Two Contrasting Lake Ecosystems. Applied and Environmental Microbiology, 70, 2941-2951. https://doi.org/10.1128/AEM.70.5.2941-2951.2004

[17] Billen, G., Servais, P. and Becquevort, S. (1990) Dynamics of Bacterioplankton in Oligotrophic and Eutrophic Aquatic Environments: Bottom-Up or Top-Down Control? Hydrobiologia, 207, 37-42. https://doi.org/10.1007/BF00041438

[18] Pradeep Ram, A.S., Colombet, J., Perriere, F., Thouvenot, A. and Sime-Ngando, T. (2015) Viral and Grazer Regulation of Prokaryotic Growth Efficiency in Temperate Freshwater Pelagic Environments. FEMS Microbiology Ecology, 91, 1-12. https://doi.org/10.1093/femsec/fiv002

[19] Tsai, A., Gong, G. and Chao, C.F. (2016) Contribution of Viral Lysis and Nanoflagellate Grazing to Bacterial Mortality at Surface Waters and Deeper Depths in the Coastal Ecosystem of Subtropical Western Pacific. Estuaries and Coasts, 39, 1357-1366. https://doi.org/10.1007/s12237-016-0098-9

[20] Takasu, H. and Nakano, S. (2017) Growth and Mortality Rates of Prokaryotes in the Hypolimnion of a Deep Freshwater Lake (Lake Biwa, Japan). Inland Waters, 7, 164-170. https://doi.org/10.1080/20442041.2017.1298222

[21] Weinbauer, M.G., Winter, C. and Höfle, M.G. (2002) Reconsidering Transmission 
Electron Microscopybased Estimates of Viral Infection of Bacterioplankton Using Conversion Factors Derived from Natural Communities. Aquatic Microbial Ecology, 27, 103-110. https://doi.org/10.3354/ame027103

[22] Weinbauer, M.G. (2004) Ecology of Prokaryotic Viruses. FEMS Microbiology Reviews, 28, 127-181. https://doi.org/10.1016/j.femsre.2003.08.001

[23] Sime-Ngando, T. (2014) Environmental Bacteriophages: Viruses of Microbes in Aquatic Ecosystems. Frontiers in Microbiology, 5, Article 355. https://doi.org/10.3389/fmicb.2014.00355

[24] Jardillier, L, Bettarel, Y., Richardot, M., Bardot, C., Amblard, C., Sime-Ngando, T. and Debroas, D. (2005) Effects of Viruses and Predators on Prokaryotic Community Composition. Microbial Ecology, 50, 557-569.

https://doi.org/10.1007/s00248-005-5030-y

[25] Tsai, A.Y., Gong, G.C., Sanders, R.W. and Huang, J. K. (2013) Contribution of Viral Lysis and Nanoflagellate Grazing to Bacterial Mortality in the Inner and Outer of the Changjiang River Plume During Summer. Journal of Plankton Research, 35, 1283-1293. https://doi.org/10.1093/plankt/fbt074

[26] Jasna, V., Parvathi, A., Pradeep Ram, A.S., Balachandran, K.K., Madhu, N.V., Nair, M., Sime-Ngando, T., et al. (2017) Viral-Induced Mortality of Prokaryotes in a Tropical Monsoonal Estuary. Frontiers in Microbiology, 8, Article 895. https://doi.org/10.3389/fmicb.2017.00895

[27] Issa, Ohba, T., Fantong, W., Fouepe, A., Chako Tchamabe, B., Yoshida, Y., Kusakabe, M., Sigha, N., Tsunogai, U., Oginuma, Y., Tanyileke, G., Satake, H. and Hell, J.V. (2013) Contribution of Methane to Total Gas Pressure in Deep Waters at Lakes Nyos and Monoun (Cameroon, West Africa). Geochemical Journal, 47, 349-362. https://doi.org/10.2343/geochemj.2.0250

[28] Aka, F.T., Yokoyama, T., Kusakabe, M., Nakamura, E., Tanyileke, G., Ateba, B., Ngako, V., Nnange, J.M. and Hell, J.V. (2008) U-Series Dating of Lake Nyos Maar Basalts, Cameroon (West Africa); Implications for Potential Hazards on the Lake Nyos. Journal of Volcanology and Geothermal Research, 176, 212-224. https://doi.org/10.1016/j.jvolgeores.2008.04.009

[29] Nagao, K., Kusakabe, M., Yoshida, Y. and Tanyileke, G. (2010) Noble Gases in Lakes Nyos and Monoun, Cameroon. Geochemical Journal, 44, 519-554. https://doi.org/10.2343/geochemj.1.0101

[30] Kusakabe, M., Ohba, T., Issa, Yoshida, Y., Satake, H., Ohizumi, T., Evans, W.C., Tanyileke, G. and Kling, G.W. (2008) Evolution of $\mathrm{CO}_{2}$ in Lakes Monoun and Nyos, Cameroon, before and during Controlled Degassing. Geochemical Journal, 42, 93-118.

[31] APHA (1998) Standard Methods for the Examination of Water and Wastewater. 20th Edition, American Public Health Association, American Water Works Association and Water Environmental Federation, Washington DC.

[32] Marie, D., Brussaard, C., Bratbak, G. and Vaulot D. (1999) Enumeration of Marine Viruses in Culture and Natural Samples by Flow Cytometry. Applied and Environmental Microbiology, 65, 45-52. https://doi.org/10.1128/AEM.65.1.45-52.1999

[33] Brussaard, C.P.D. (2004) Optimization of Procedures for Counting Viruses by Flow Cytometry. Applied and Environmental Microbiology, 70, 1506-1513. https://doi.org/10.1128/AEM.70.3.1506-1513.2004

[34] Duhamel, S. and Jacquet, S. (2006) Flow Cytometric Analysis of Bacteria and Virus-Like Particles in Lake Sediments. Journal of Microbiological Methods, 64, 316-322. https://doi.org/10.1016/j.mimet.2005.05.008 
[35] Lefranc, M., Thénot, A., Lepère, C. and Debroas, D. (2005) Genetic Diversity of Small Eukaryotes in Lakes Differing by Their Trophic Status. Applied and Environmental Microbiology, 71, 5935-5942. https://doi.org/10.1128/AEM.71.10.5935-5942.2005

[36] Wang, Y. and Qian, P.Y. (2009) Conservative Fragments in Bacterial 16S rRNA Genes and Primer Design for 16S Ribosomal DNA Amplicons in Metagenomic Studies. PLoS ONE, 4, e7401. https://doi.org/10.1371/journal.pone.0007401

[37] Kim, W., Bennett, E., Huttlin, E., Guo, A., Li, J., Possemato, A., Sowa, M., Rad, R., Rush, J., Comb, M., Harper, J.W. and Gygi, S. (2011) Systematic and Quantitative Assessment of the Ubiquitin-Modified Proteome. Molecular Cell, 44, 325-340. https://doi.org/10.1016/j.molcel.2011.08.025

[38] Pruesse, E., Quast, C., Knittel, K., et al. (2007) SILVA, a Comprehensive Online Resource for Quality Checked and Aligned Ribosomal RNA Sequence Data Compatible with ARB. Nucleic Acids Research, 35, 7188-7196. https://doi.org/10.1093/nar/gkm864

[39] Price, M.N., Dehal, P.S. and Arkin, A.P. (2010) Fast Tree 2-Approximately Maximum-Likelihood Trees for Large Alignments. PLoS ONE, 5, e9490. https://doi.org/10.1371/journal.pone.0009490

[40] Taib, N., Mangot, J.-F., Domaizon, I., Bronner, G. and Debroas, D. (2013) Phylogenetic Affiliation of SSU rRNA Genes Generated by Massively Parallel Sequencing: New Insights into the Freshwater Protist Diversity. PLoS ONE, 8, e58950. https://doi.org/10.1371/journal.pone.0058950

[41] McMurdie, P.J. and Holmes, S. (2013) phyloseq: An R Package for Reproducible Interactive Analysis and Graphics of Microbiome Census Data. PLoS ONE, 8, e61217. https://doi.org/10.1371/journal.pone.0061217

[42] Paul, D., Kumbhare, S.V., Mhatre, S.S., Chowdhury, S.P., Shetty, S.A., Marathe, N.P., Shouche, Y.S., et al. (2015) Exploration of Microbial Diversity and Community Structure of Lonar Lake: The Only Hypersaline Meteorite Crater Lake within Basalt Rock. Frontiers in Microbiology, 6, 1553. https://doi.org/10.3389/fmicb.2015.01553

[43] Newton, R.J., Jones, S.E., Eiler, A., McMahon, K.D. and Bertilsson, S. (2011) A Guide to the Natural History of Freshwater Lake Bacteria. Microbiology and Molecular Biology Reviews, 75, 14-49. https://doi.org/10.1128/MMBR.00028-10

[44] Zwart, G., Crump, B.C., Agterveld, M.P.K.V., Hagen, F. and Han, S.K. (2002) Typical Freshwater Bacteria: An Analysis of Available 16S rRNA Gene Sequences from Plankton of Lakes and Rivers. Aquatic Microbial Ecology, 28, 141-155. https://doi.org/10.3354/ame028141

[45] Humbert, J.-F., Dorigo, U., Cecchi, P., Le Berre, B., Debroas, D. and Bouvy, M. (2009) Comparison of the Structure and Composition of Bacterial Communities from Temperate and Tropical Freshwater Ecosystems. Environmental Microbiology, 11, 2339-2350. https://doi.org/10.1111/j.1462-2920.2009.01960.x

[46] Hideyuki, T., Yuji, S., Satoshi, H. and Kazunori, N. (2005) Comparative Analysis of Bacterial Diversity in Freshwater Sediment of a Shallow Eutrophic Lake by Molecular and Improved Cultivation-Based Techniques. Environmental Science \& Technology, 71, 2162-2169. https://doi.org/10.1128/AEM.71.4.2162-2169.2005

[47] Schwarz, J.I.K., Eckert, W. and Conrad, R. (2007) Community Structure of Archaea and Bacteria in a Profundal Lake Sediment Lake Kinneret (Israel). Systematic and Applied Microbiology, 30, 239-254. https://doi.org/10.1016/j.syapm.2006.05.004

[48] De Wever, A., Muylaert, K., Van der Gucht, K., Pirlot, S., Cocquyt, C., Descy, J.P., 
Plisnier, P.D. and Vyverman, W. (2005) Bacterial Community Composition in Lake Tanganyika: Vertical and Horizontal Heterogeneity. Applied and Environmental Microbiology, 71, 5029-5037. https://doi.org/10.1128/AEM.71.9.5029-5037.2005

[49] Meyer, B.S., Matschiner, M. and Salzburger, W. (2015) A Tribal Level Phylogeny of Lake Tanganyika Cichlid Fishes Based on a Genomic Multi-Marker Approach. Molecular Phylogenetics and Evolution, 83, 56-71.

https://doi.org/10.1016/j.ympev.2014.10.009

[50] İnceoğlu, Ö., Llirós, M., Crowe, S.A., García-Armisen, T., Morana, C., Darchambeau, F., Borges, A.V., Descy, J.P. and Servais, P. (2015) Vertical Distribution of Functional Potential and Active Microbial Communities in Meromictic Lake Kivu. Microbial Ecology, 70, 596-611. https://doi.org/10.1007/s00248-015-0612-9

[51] Lliros, M., Gich, F., Plasencia, A., Auguet, J.-C., Darchambeau, F., Casamayor, E.O., Descy, J.-P. and Borrego, C. (2010) Vertical Distribution of Ammonia-Oxidizing Crenarchaeota and Methanogens in the Epipelagic Waters of Lake Kivu (Rwanda-Democratic Republic of the Congo). Applied and Environmental Microbiology, 76, 6853-6863. https://doi.org/10.1128/AEM.02864-09

[52] Suttle, C.A. (2005) Viruses in the Sea. Nature, 437, 356-361. https://doi.org/10.1038/nature04160

[53] Sime-Ngando, T., Bettarel, Y., Colombet, J., Palesse, S., Angia Sriram, P.R., Charpin, M. and Amblard, C. (2016) Lake Pavin: A Pioneer Site for Ecological Studies of Freshwater Viruses. In: Sime-Ngando, T., Boivin, P., Chapron, E., Jezequel, D. and Meybeck, M., Eds., Lake Pavin, Springer, Cham, 229-244.

https://doi.org/10.1007/978-3-319-39961-4

[54] He, T., Li, H. and Zhang, X. (2017) Deep-Sea Hydrothermal Vent Viruses Compensate for Microbial Metabolism in Virus-Host Interactions. mBio, 8, e00893-17. https://doi.org/10.1128/mBio.00893-17

[55] Wommack, K.E. and Colwell, R.R. (2000) Virioplankton: Viruses in Aquatic Ecosystems. Microbiology and Molecular Biology Reviews, 64, 69-114. https://doi.org/10.1128/MMBR.64.1.69-114.2000

[56] Zhong, X., Pradeep Ram, A.S., Colombet, J. and Jacquet, S. (2014) Variations in Abundance, Genome Size, Morphology and Functional Role of the Virioplankton in Lakes Annecy and Bourget over a 1-Year Period. Microbiology Ecology, 67, 66-82. https://doi.org/10.1007/s00248-013-0320-2

[57] Clokie, M.R., Millard, A.D., Letarov, A.V. and Heaphy, S. (2011) Phages in Nature. Bacteriophage, 1, 31-45. https://doi.org/10.4161/bact.1.1.14942

[58] Weinbauer, M.G. and Rassoulzadegan, F. (2004) Are Viruses Driving Microbial Diversification and Diversity? Environmental Microbiology, 6, 1-11. https://doi.org/10.1046/j.1462-2920.2003.00539.x

[59] Rugema, E., Darchambeau, F., Sarmento, H., Stoyneva-Gärtner, M., Wim Thiery, Leitao, M., Latli, A. and Descy, J.-P. (2019) Long-Term Change of Phytoplankton in Lake Kivu: The Rise of the Greens. Freshwater Biology, 64, 1940-1955. https://doi.org/10.1111/fwb.13383

[60] Descy, J.-P., Darchambeau, F. and Schmid, M. (2012) Lake Kivu: Limnology and Biogeochemistry of a Tropical Great Lake (Aquatic Ecology Series 5). Springer, Berlin, 1-11. https://doi.org/10.1007/978-94-007-4243-7_ 1

[61] Kirchman, D.L. (2002) Microbial Ecology of the Oceans. Wiley Liss, New York, 543 p.

[62] Llirós, M., Descy, J.-P., Libert, X., Morana, C., Schmitz, M., Wimba, L., Nzavuga-Izere, A., Tamara, G.-A., Borrego, C., Servais, P. and Darchambeau, F. (2012) Microbial 
Ecology of Lake Kivu. In: Descy, J.-P., Darchambeau, F. and Schmid, M., Eds., Lake Kivu: Limnology and Biogeochemistry of a Tropical Great Lake, Springer, Berlin, 85-105. https://doi.org/10.1007/978-94-007-4243-7 6

[63] González, J.M. and Moran, M.A. (1997) Numerical Dominance of a Group of Marine Bacteria in the Alpha-Subclass of the Class Proteobacteria in Coastal Seawater. Applied and Environmental Microbiology, 63, 4237-4242. https://doi.org/10.1128/AEM.63.11.4237-4242.1997

[64] Troussellier, M., Schäfer, H., Batailler, N., Bernard, L., Courties, C., Lebaron, P., Muyzer, G., Servais, P. and Vives-Rego, J. (2002) Bacterial Activity and Genetic Richness along an Estuarine Gradient (Rhone River Plume, France). Aquatic Microbial Ecology, 28, 13-24. https://doi.org/10.3354/ame028013

[65] Kretz, C.B., Bell, D.W., Lomas, D.A., Lomas, M.W. and Martiny, A.C. (2015) Influence of Growth Rate on the Physiological Response of Marine Synechococcus to Phosphate Limitation. Frontiers in Microbiology, 6, 85

https://doi.org/10.3389/fmicb.2015.00085

[66] Romano, S., Bondarev, V., Kölling, M., Dittmar, T. and Schulz-Vogt, H.N. (2017) Phosphate Limitation Triggers the Dissolution of Precipitated Iron by the Marine Bacterium pseudovibrio sp. FO-BEG1. Frontiers in Microbiology, 8, 364. https://doi.org/10.3389/fmicb.2017.00364

[67] Meunier, A. and Jacquet, S. (2015) Do Phages Impact Microbial Dynamics, Prokaryotic Community Structure and Nutrient Dynamics in Lake Bourget? Biology Open, 4, 1528-1537. https://doi.org/10.1242/bio.013003

[68] Colombet, J., Sime-Ngando, T., Cauchie, H.M., Fonty, G., Hoffmann, L. and Demeure, G. (2006) Depth-Related Gradients of Viral Activity in Lake Pavin. Applied and Environmental Microbiology, 72, 4440-4445. https://doi.org/10.1128/AEM.00021-06

[69] Keshri, J., Pradeep Ram, A.S., Nana, P.A. and Sime-Ngando, T. (2018) Taxonomical Resolution and Distribution of Bacterioplankton along the Vertical Gradient Reveals Pronounced Spatiotemporal Patterns in Contrasted Temperate Freshwater Lakes. Microbial Ecology, 76, 372-386. https://doi.org/10.1007/s00248-018-1143-y

[70] Thomas, R., Berdjeb, L., Sime-Ngando, T. and Jacquet, S. (2011) Viral Abundance, Production, Decay Rates and Life Strategies (Lysogeny versus Lysis) in Lake Bourget (France). Environmental Microbiology, 13, 616-630. https://doi.org/10.1111/j.1462-2920.2010.02364.x

[71] Säwström, C., Pearce, I., Davidson, A.T., Rosén, P. and Laybourn-Parry, J. (2007) Influence of Environmental Conditions, Bacterial Activity and Viability on the Viral Component in 10 Antarctic Lakes. FEMS Microbiology Ecology, 63, 12-22. https://doi.org/10.1111/j.1574-6941.2007.00407.x

[72] Wilhelm, S.W., Weinbauer, M.G., Suttle, C.A. and Jeffrey, W.H. (1998) The Role of Sunlight in the Removal and Repair of Viruses in the Sea. Limnology and Oceanography, 43, 586-592. https://doi.org/10.4319/10.1998.43.4.0586

[73] Dann, L.M., Paterson, J.S., Newton, K., Oliver, R. and Mitchell, J.G. (2016) Distributions of Virus-Like Particles and Prokaryotes within Microenvironments. PLoS ONE, 11, e0146984. https://doi.org/10.1371/journal.pone.0146984

[74] Bronner, G., Debroas, D., Enault, F., Hugoni, M., Jouan-Dufournel, I., Mary, I., Ravet, V., Roux, S. and Taïb, N. (2016) Study of Prokaryotes and Viruses in Aquatic Ecosystems by Metagenetic and Metagenomic Approaches. In: Sime-Ngando, T., Boivin, P., Chapron, E., Jezequel, D. and Meybeck, M., Eds., Lake Pavin, Springer, Cham, 245-254. https://doi.org/10.1007/978-3-319-39961-4 15 